\title{
CYP19A1 gene expression in the peripheral blood of Brazilian women with breast cancer relapse
}

\author{
Maria da Conceição Barros-Oliveira 1,2, Danylo Rafhael Costa-Silva ${ }^{1,2}$, Larysse Cardoso Campos-Verdes ${ }^{1,2}$, \\ Renato de Oliveira Pereira ${ }^{3}$, Rozirene Araújo Silva ${ }^{3}$, Paulo de Tarso Moura-Borges ${ }^{3}$, Emerson Brandão Sousa ${ }^{3}$, \\ André Luiz Pinho-Sobral ${ }^{3}$, Pedro Vitor Lopes-Costa ${ }^{3}$, Alesse Ribeiro dos Santos ${ }^{3}$, Ione Maria Ribeiro Soares-Lopes ${ }^{3}$, \\ Jackeline Lopes Viana ${ }^{3}$, Mariella de Almeida Melo ${ }^{3}$, Fidelis Manes Neto ${ }^{3}$, Eid Gonçalves Coelho ${ }^{1,2}$, \\ Maria do Socorro Pires e Cruz ${ }^{1,2}$, Vladimir Costa-Silva ${ }^{1,2}$, Luiz Henrique Gebrim ${ }^{1,2,4}$ and \\ Benedito Borges Da Silva ${ }^{1,2,3^{*}}$ (D)
}

\begin{abstract}
Background: The CYP19A1 gene, which encodes the enzyme responsible for androgen aromatization into estrogens, may play an important role in breast cancer aggressiveness. However, no study has evaluated CYP19A1 gene expression in the peripheral blood of women with relapsed breast cancer.

Methods: In this cross-sectional study, CYP19A1 gene expression was quantified by RT-PCR in the peripheral blood of 146 women with breast cancer who were first divided into two groups according to the expression of CYP19A1 (low and high); each group had 73 patients. Subsequently, women were divided into two groups: those without recurrence (control, $n=85$ ) and those with recurrence (study, $n=61$ ). Statistical analysis of the data was performed using ANOVA, the Mann-Whitney, Chi-square or Fisher's exact test $(p<0.05)$.

Results: There were no significant differences between the relative expression of CYP19A1 mRNA in the low expression group and the high expression group according to the variables studied. There were no significant differences in CYP19A1 gene expression in the study and control groups $(p=0.8461)$. In the relapse group, CYP19A1 gene expression was significantly higher in the hybrid luminal subtype than in the triple-negative subtype ( $p=$ 0.0321), whereas it was significantly lower in HER2-negative cases than in HER2-positive cases $(p<0.0376)$. Women with locoregional recurrence showed higher expression than women with distant recurrence $(p<0.0001)$.

Conclusions: The present study found no significant differences between women with high and low expression of the CYP19A1 gene mRNA or between those in the study group and the control group. However, in women with recurrence, there was increased expression of CYP19A1 mRNA in those who had the luminal hybrid subtype and locoregional relapse and decreased expression in those negative for HER2.
\end{abstract}

Keywords: Breast cancer, CYP19A1, Gene expression, Relapse

\footnotetext{
* Correspondence: beneditoborges@globo.com

${ }^{1}$ Postgraduate Program of the Northeast Network of Biotechnology

(RENORBIO), Teresina, Northeast, Brazil

${ }^{2}$ Federal University of Piaui, Teresina, Piaui, Brazil

Full list of author information is available at the end of the article
}

C C The Author(s). 2020 Open Access This article is licensed under a Creative Commons Attribution 4.0 International License, which permits use, sharing, adaptation, distribution and reproduction in any medium or format, as long as you give appropriate credit to the original author(s) and the source, provide a link to the Creative Commons licence, and indicate if changes were made. The images or other third party material in this article are included in the article's Creative Commons licence, unless indicated otherwise in a credit line to the material. If material is not included in the article's Creative Commons licence and your intended use is not permitted by statutory regulation or exceeds the permitted use, you will need to obtain permission directly from the copyright holder. To view a copy of this licence, visit http://creativecommons.org/licenses/by/4.0/. The Creative Commons Public Domain Dedication waiver (http://creativecommons.org/publicdomain/zero/1.0/) applies to the data made available in this article, unless otherwise stated in a credit line to the data. 


\section{Background}

Breast cancer is the most common malignancy affecting women worldwide, and in 2018, the global estimate of impacted women was approximately 2,089,000, with a mortality rate of nearly $627,000[1,2]$. Its incidence is higher in the most developed regions of the world compared to developing and underdeveloped regions [3].

In Brazil, which is a developing country, breast cancer is the second most common malignancy in women after non-melanoma skin cancer, with an estimated 59,700 new cases and 15,403 cases of death from the disease in 2018 [4]. Additionally, approximately 40\% of patients who develop disease recurrence die, especially in the first 2 to 3 years, when the risk of recurrence is higher [5-7]. Although physical examination and mammography are important to ensure early diagnosis of the disease and to reduce mortality, breast cancer is still frequently diagnosed in advanced stages in Brazil, resulting in high mortality rates, even with the current therapeutic strategies [8].

It has been suggested that the most appropriate therapeutic and prognostic strategies for breast cancer may be developed using genes that are associated with the development, growth and aggressiveness of breast cancer as biomarkers $[9,10]$. This includes the CYP19A1 gene that encodes the aromatase enzyme, which is involved in estrogen biosynthesis, as it promotes androgen aromatization in estrogens $[11,12]$. The CYP19A1 gene has been studied as a prognostic marker of breast cancer due to its genetic control in estrogen biosynthesis [13, 14]. This gene has tissue-specific promoters, and principally, normal breast adipose tissue maintains low levels of aromatase expression primarily via the I.4 distal promoter. However, in breast cancer, an exchange between the I.4 and I.3 promoters and the I.7 and II promoters occurs, leading to increased production of aromatase and local estrogen $[15,16]$.

Some studies have examined CYP19A1 gene expression in breast cancer using quantitative reverse transcription polymerase chain reaction (RT-PCR), which is considered a standard method for the quantitative measurement of gene expression; however, many of these studies have shown controversial results [16, 17]. Miyoshi et al. found no significant association between CYP19A1 expression levels and breast cancer [18]. On the other hand, Friesenhengst et al. evaluated CYP19A1 expression in tumors of women with breast cancer, and the results showed a significant association between high CYP19A1 gene expression and estrogen receptor expression, menopausal status, metastasis-free survival, overall survival, disease-free survival and local and distant recurrence [11]. Thus, the controversies surrounding the gene expression of CYP19A1 in breast tumor studies and, to the best of our knowledge, the absence of studies analyzing the peripheral blood of women with recurrent breast cancer led to the design of this study.

\section{Methods \\ Patients}

This cross-sectional study involved 146 women from 34 to 80 years of age who had breast cancer and received care at the Mastology Clinic of Perola Byington Hospital (Sao Paulo, Brazil) between July and September 2018. The Internal Review Board of the Federal University of Piau and Perola Byington Hospital approved the study under number CAAE: 43447015.8.0000, and all the patients signed an informed consent form prior to admission. The women were first divided into two groups, with low and high expression of CYP19A1 with 73 patients each. Subsequently, women were divided into two groups, without recurrence (control, $n=85$ ) and with recurrence (study, $n=61$ ). Women who were over 18 years of age, with and without breast cancer recurrence in the operable stage, who were diagnosed and treated in the past 10 years and had histologically confirmed diagnoses (disease at diagnosis) were included in the study. Women with a history of another neoplasm, a serious concomitant disease or an initial diagnosis of metastatic breast cancer were excluded from the study.

\section{Blood sampling}

Peripheral blood was collected by a specialized technician using a disposable syringe and needle after medical consultation. The first $1 \mathrm{~mL}$ of peripheral blood was discarded to prevent contamination by epidermal cells. A 1 $\mathrm{mL}$ sample of total peripheral blood from each patient was preserved in $3 \mathrm{~mL}$ TRIzol (Invitrogen; Thermo Fisher Scientific, Inc.) and stored at $-80{ }^{\circ} \mathrm{C}$ until RNA extraction.

\section{Total RNA extraction and CDNA synthesis}

RNA extraction was performed using TRIzol reagent (Invitrogen; Thermo Fisher Scientific, Inc.) according to the manufacturer's instructions. RNA concentration, integrity and purity were analyzed using a NanoDrop 1000 spectrophotometer (Thermo Fisher Scientific, Inc.) and agarose gel electrophoresis. Complementary DNA (cDNA) was synthesized from 2000 ng RNA using SuperScript III First-Strand Synthesis System (Invitrogen; Thermo Fisher Scientific, Inc.) with a total reaction volume of $20 \mu \mathrm{L}$ containing $50 \mu \mathrm{M}$ Oligo (dT) 20, 10 mM DNTP, $1 \mathrm{~mL}$ 10X RT buffer, 0.1 M DTT, $40 \mathrm{U} / \mu \mathrm{L}$ RNaseOUT and $200 \mathrm{U} / \mu \mathrm{l}$ SuperScript III RT. The incubation conditions for reverse transcription (RT) were $50{ }^{\circ} \mathrm{C}$ for $60 \mathrm{~min}$ and $70{ }^{\circ} \mathrm{C}$ for $15 \mathrm{~min}$. The samples were placed in long-term storage at $4{ }^{\circ} \mathrm{C}$. The cDNA was kept at $-20^{\circ} \mathrm{C}$ and was diluted 10 -fold prior to use in the quantitative RT-PCR. 


\section{Quantitative RT-PCR}

CYP19A1 mRNA expression was determined by quantitative RT-PCR using Power SYBR Green PCR Master Mix (Applied Biosystems; Thermo Fisher Scientific, Inc.) and an ABI 7500 detection system equipped with SDS v1.4 software. The following primers were used for detection and quantitation of CYP19A1 mRNA: sense primer, 5'-CACATCCTCAATACCAGGTCC-3'; antisense primer, 5' -CAGAGATCCAGACTCGCATG-3'. $B E T A-A C T I N$ (ACTB) was used as an endogenous normalization control. The following primers were used for $A C T B$ : sense primer, 5'-CACTGTGTTGGCGT ACAGGT-3' and antisense primer, 5'-AAATCTGGCA CCACACCTTC-3'. Reactions were performed in a final volume of $13 \mu \mathrm{L}$, containing $3 \mu \mathrm{L}$ DNA sample, $6.4 \mu \mathrm{L}$ SYBR Green Master Mix (Applied Biosystems; Thermo Fisher Scientific, Inc.), $0.4 \mu \mathrm{L}$ primers (Custom TaqMan Gene Expression Assays, Applied Biosystems; Thermo Fisher Scientific, Inc.), and $2.9 \mu \mathrm{L}$ of ultrapure sterile water, in 96-well plates using the StepOne Real-Time PCR System (Applied Biosystems, Foster City, CA, USA). After initial denaturation for $10 \mathrm{~min}$ at $95^{\circ} \mathrm{C}$, the samples were subjected to 40 amplification cycles, consisting of two steps: $15 \mathrm{~s}$ at $95^{\circ} \mathrm{C}$ and $1 \mathrm{~min}$ at $60{ }^{\circ} \mathrm{C}$. Samples were evaluated in duplicate, and two negative controls were added to each plate containing the same reaction compounds, but the DNA sample was replaced with water. Relative quantitation of CYP19A1 mRNA expression as a target was performed using the $2 \wedge-\Delta C T$ method using the mean values obtained from the threshold cycle (CT) of 146 samples and the ACTB CT values as an endogenous control.

\section{Statistical analysis}

To evaluate the associations between CYP19A1 expression and clinical and histopathologic variables, the Mann-Whitney, Chi-square or Fisher's exact test and unidirectional ANOVA with multiple comparisons were performed using the Bonferroni post-test method. The values of $p<0.05$ were interpreted as statistically significant. All statistical analyses were performed with GraphPad Prism software 6.0 (GraphPad Software, San Diego, CA, USA).

\section{Results}

\section{Correlations between CYP19A1 mRNA levels and histopathologic features}

Using the median as the cut-off point, the patients were divided in low expression group and high expression group of CYP19A1. There were no significant differences between the relative expression of CYP19A1 mRNA in the low expression group and the high expression group according to the variables studied (Table 1). Patients were classified according to their sensitivity to endocrino therapy (ET) based on 2nd international consensus guidelines for advanced breast cancer, developed by European School of Oncology and European Society of Medical Oncology [19], responsive to ET, when relapses occur after 2 years of adjuvant ET or resistant when a relapses occurs in the first 2 years of adjuvant ET. In the current study, $44.27 \%$ of patients were considered responsive to endocrine therapy and $55.73 \%$ considered unresponsive.

\section{Association of relative expression of CYP19A1 mRNA with the clinical and histopathologic features}

There were no significant differences in the relative expression of CYP19A1 mRNA in the study group compared to the control, $\mathrm{p}=0.8461$ (Fig. 1). In the study group, CYP19A1 mRNA expression was significantly higher in patients with a hybrid luminal molecular subtype than in patients with a triple-negative subtype, $\mathrm{p}=$ 0.0321 (Fig. 2). There were no significant differences in the relative expression of CYP19A1 mRNA in women with locoregional recurrence in the pre or post menopause $(\mathrm{p}=0.116)$. No other associations were observed between the relative expression of CYP19A1 mRNA and the other variables studied, such as age, use of tobacco, menopausal status, grade, nodal status $(\mathrm{N})$, tumor stage, estrogen and progesterone receptor, HER2 and histological type.

\section{Correlations between the median expression levels of CYP19A1 mRNA and histopathologic features according to} recurrence

Using the median as the cut-off point, the median expression of CYP19A1 mRNA was classified as high or low and then analyzed to determine its association with clinical and histopathological features (Table 2). The group of women with recurrence of breast cancer and negative HER2 receptor expression showed reduced CYP19A1 mRNA levels compared to those with positive HER2 receptor expression $(\mathrm{p}<0.0376)$. Further, the mRNA expression of CYP19A1 was significantly higher in women with locoregional recurrence than in women with distant recurrence $(\mathrm{p}<0.0001)$. There was no significant difference between the expression of CYP19A1 and the other variables studied.

\section{Discussion}

The detection of circulating CYP19A1 mRNA by RTPCR has been shown to be significantly increased in breast cancer compared to normal controls, and quantitative RT-PCR is considered a sensitive and reliable method for studying mRNA in a variety of sites, such as bone marrow, lymph nodes, tissues and blood [20-23]. However, according to a survey of the literature, the evaluation of CYP19A1 mRNA by quantitative RT-PCR 
Table 1 Correlations between the levels of CYP19A1 mRNA and histopathologic features in women with breast cancer

\begin{tabular}{|c|c|c|c|c|}
\hline \multirow{2}{*}{$\begin{array}{l}\text { Variables } \\
\text { Median age, } 54 \text { y } \\
\text { (range, 34-82 y) } \\
\end{array}$} & \multirow[t]{2}{*}{ N (\%) } & \multicolumn{2}{|l|}{ CYP19A1 Expression } & \multirow[t]{2}{*}{$\boldsymbol{p}$ value } \\
\hline & & Low (\%) & High (\%) & \\
\hline \multicolumn{5}{|l|}{ Age } \\
\hline$\leq 50$ years & $60(41.1)$ & $31(21.2)$ & $29(19.9)$ & \multirow[t]{2}{*}{0.73} \\
\hline$>51$ years & $86(58.9)$ & $42(28.8)$ & $44(30.1)$ & \\
\hline \multicolumn{5}{|l|}{ Tobacco use } \\
\hline Yes & $55(37.7)$ & $30(20.5)$ & $25(17.1)$ & \multirow[t]{2}{*}{0.39} \\
\hline No & $91(62.3)$ & $43(29.5)$ & $48(32.9)$ & \\
\hline \multicolumn{5}{|l|}{ Menopausal status } \\
\hline Premenopausal & $63(43.2)$ & $31(21.2)$ & $32(21.9)$ & \multirow[t]{2}{*}{0.86} \\
\hline Postmenopausal & $83(56.8)$ & $42(28.8)$ & $41(28.1)$ & \\
\hline \multicolumn{5}{|l|}{ Tumor Grade } \\
\hline G1 & $14(9.6)$ & $3(2.1)$ & $11(7.5)$ & \multirow[t]{3}{*}{0.07} \\
\hline $\mathrm{G} 2$ & 107 (73.3) & $57(39.0)$ & $50(34.2)$ & \\
\hline G3 & $25(17.1)$ & $13(8.9)$ & $12(8.2)$ & \\
\hline \multicolumn{5}{|l|}{ N Classification } \\
\hline No-N1 & $127(87.0)$ & $62(42.5)$ & $65(44.5)$ & \multirow[t]{2}{*}{0.46} \\
\hline N2-N3 & $19(13.0)$ & $11(7.5)$ & $8(5.5)$ & \\
\hline \multicolumn{5}{|l|}{ Tumor stage } \\
\hline I & $19(13.0)$ & $7(4.8)$ & $12(8.2)$ & \multirow[t]{3}{*}{0.40} \\
\hline$\|$ & $74(50.7)$ & $40(27.4)$ & $34(23.3)$ & \\
\hline III & $53(36.3)$ & $26(17.8)$ & $27(18.5)$ & \\
\hline \multicolumn{5}{|l|}{ Molecular subtype } \\
\hline Luminal A & $16(11.0)$ & $6(4.1)$ & $10(6.8)$ & \multirow[t]{5}{*}{0.06} \\
\hline Luminal B & $68(45.2)$ & $36(24.7)$ & $32(21.9)$ & \\
\hline Her2 overexpression & $23(15.8)$ & $12(8.2)$ & $11(7.5)$ & \\
\hline Triple-negative & $31(21.2)$ & 19 (13.0) & $12(8.2)$ & \\
\hline Hybrid Luminal & $8(6.8)$ & $8(5.5)$ & $0(0.0)$ & \\
\hline \multicolumn{5}{|l|}{ Estrogen receptors } \\
\hline Positive Negative & 105 (71.9) 41 (28.1) & 52 (35.6) 21 (14.4) & 53 (36.3) 20 (13.7) & 0.85 \\
\hline \multicolumn{5}{|l|}{ Progesterone receptors } \\
\hline Positive Negative & 97 (66.4) 49 (33.6) & 49 (33.6) 24 (16.4) & 48 (32.9) 25 (17.1) & 0.86 \\
\hline \multicolumn{5}{|l|}{ HER2 } \\
\hline Positive Negative & $35(24.0) 111(76.0)$ & $14(9.6) 59(40.4)$ & 21 (14.4) 52 (35.6) & 0.17 \\
\hline \multicolumn{5}{|l|}{ Histological type } \\
\hline Ductal & $104(71.2)$ & $50(34.2)$ & $54(37.0)$ & \multirow[t]{3}{*}{0.73} \\
\hline Lobular & $8(5.5)$ & $4(2.7)$ & $4(2.7)$ & \\
\hline Other & $34(23.3)$ & 19 (13.0) & $15(10.3)$ & \\
\hline \multicolumn{5}{|l|}{ Recurrence } \\
\hline Yes & $61(41.8)$ & $32(21.9)$ & $29(19.9)$ & \multirow[t]{2}{*}{0.61} \\
\hline No & $85(58.2)$ & $41(28.1)$ & $44(30.1)$ & \\
\hline
\end{tabular}




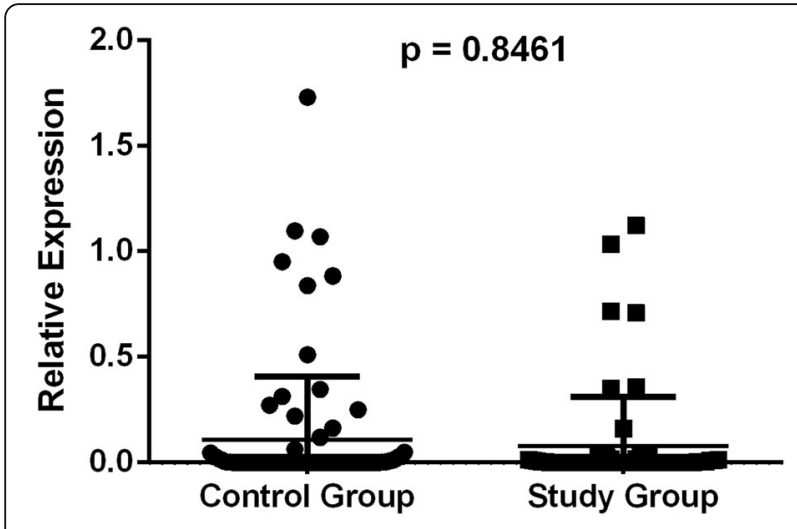

Fig. 1 Relative expression of CYP19A1 mRNA in the study group compared to that in the control group

in the total blood of women with breast cancer recurrence was not reported, but some studies solely involving normal, peritumoral and tumoral tissues are available [11, 18]. Peripheral blood has been used as a clinical sample for gene expression analysis in breast cancer, since peripheral blood samples are readily available, their acquisition is minimally invasive and they can be collected at low cost, thus making them an attractive alternative modality for diagnostic and prognostic purposes in cancer research [24, 25]. According to some authors, there is a correlation between CYP19A1 mRNA levels in peripheral blood leukocytes and target tissues [26, 27].

In the present study, comparison of peripheral blood CYP19A1 gene expression levels by quantitative RT-PCR between women with low and high expression and women with nonrelapsed breast cancer (control) and women with relapsed cancer (study) showed no statistically significant differences. In the group with relapsed

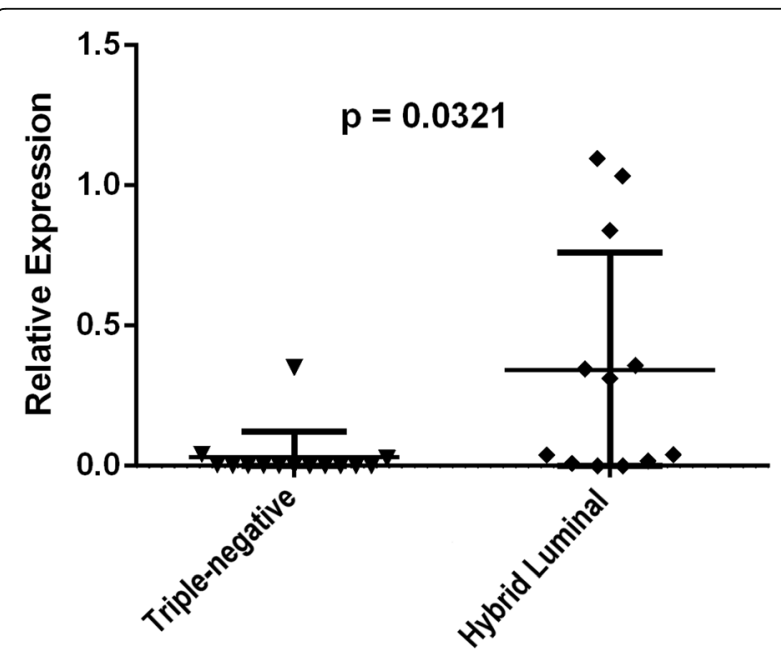

Fig. 2 Relative expression of CYP19A1 mRNA in the relapse group of women who had the hybrid luminal molecular subtype compared to that in those with the triple negative subtype cancer, CYP19A1 gene expression was significantly higher in women with a hybrid luminal molecular subtype than in women with a triple-negative subtype. Regarding tumor characteristics, the group of women with breast cancer recurrence showed a significant reduction in CYP19A1 mRNA in women with HER2-negative tumors compared to those with HER2-positive tumors. Additionally, CYP19A1 mRNA expression was significantly higher in women with locoregional recurrence than in those with distant recurrence, and there was no difference in relation to the other variables studied.

On evaluating the expression of the CYP19A1 gene in breast cancer tissue, Friesenhengst et al. [11] detected an association between the high expression of CYP19A1 in breast tumors and the incidence of breast cancer recurrence. However, consistent with our results, Girault et al. [28] and Licznerska et al. [29] evaluated CYP19A1 gene expression in breast cancer tissue and found no associations between CYP19A1 mRNA levels and disease recurrence. Darlix et al. [30] showed longer survival in women with hybrid luminal breast cancer than in those with triplenegative breast cancer, while other authors, such as Friesenhengst et al. [11] and Brown et al. [31], showed no association between CYP19A1 mRNA expression levels and molecular subtypes of breast cancer. However, these studies were performed in tumor tissue and had a smaller sample size than the present study.

Some authors have not shown an association between CYP19A1 gene expression in women with breast cancer and HER2 receptor status [11, 32, 33]. However, findings similar to those in this study were found by Subbaramaiah et al. [34], who showed lower levels of aromatase enzyme and CYP19A1 activity in HER2-negative tumors than in HER2-positive tumors. Some authors have shown that HER2 overexpression is the main determinant of increased expression of cyclooxygenase- 2 and synthesis of prostaglandin E2 in breast tumor cells, which in turn, leads to increased CYP19A1 gene expression and aromatase activity [34-36].

Bollet et al. [32] showed a significant association between low expression of the CYP19A1 gene and an increased risk of locoregional recurrence. On the other hand, other studies have shown an association between the complete absence of CYP19A1 gene expression and shorter relapse-free survival $[29,37]$. Furthermore, consistent with our results, Friesenhengst et al. [11] and Salhab et al. [33] reported that high expression of the CYP19A1 gene was associated with increased locoregional recurrence. Estrogen synthesis in situ is believed to be primarily catalyzed by the enzyme aromatase, which is often overexpressed in breast tumors, thus explaining the increased levels of CYP19A1 mRNA in patients with 
Table 2 Correlations between the median expression levels of CYP19A1 mRNA and histopathologic features according to relapse

\begin{tabular}{|c|c|c|c|c|c|c|}
\hline \multirow[t]{3}{*}{ Variables } & \multicolumn{2}{|l|}{ Relapse $(\boldsymbol{n}=61)$} & \multirow[t]{3}{*}{$\boldsymbol{P}$ values } & \multicolumn{2}{|c|}{ Nonrelapsed $(\boldsymbol{n}=85)$} & \multirow{3}{*}{$\boldsymbol{P}$ values } \\
\hline & \multirow{2}{*}{$\begin{array}{l}\text { Low } \\
\text { n (\%) }\end{array}$} & \multirow{2}{*}{$\begin{array}{l}\text { High } \\
\text { n (\%) }\end{array}$} & & \multirow{2}{*}{$\begin{array}{l}\text { Low } \\
\text { n (\%) }\end{array}$} & \multirow{2}{*}{$\begin{array}{l}\text { High } \\
\text { n (\%) }\end{array}$} & \\
\hline & & & & & & \\
\hline \multicolumn{7}{|l|}{ Age } \\
\hline$\leq 50$ years & $13(21.3)$ & $12(19.7)$ & 0.877 & $19(22.4)$ & $16(18.8)$ & 0.568 \\
\hline$>51$ years & $18(29.5)$ & $18(29.5)$ & & $24(28.2)$ & $26(30.6)$ & \\
\hline \multicolumn{7}{|l|}{ Tobacco use } \\
\hline Yes & $13(21.3)$ & $10(16.4)$ & 0.488 & $18(21.2)$ & $14(16.5)$ & 0.327 \\
\hline No & $18(29.5)$ & $20(32,8)$ & & $24(28.2)$ & $29(34.1)$ & \\
\hline \multicolumn{7}{|l|}{ Menopausal status } \\
\hline Premenopausal & $12(19.7)$ & $14(23.0)$ & 0.529 & $20(23.5)$ & $17(20.0)$ & 0.574 \\
\hline Postmenopausal & 19 (31.1) & $16(26.2)$ & & $23(27.1)$ & $25(29.4)$ & \\
\hline \multicolumn{7}{|l|}{ Tumor Grade } \\
\hline G1 & $0(0.0)$ & $4(6.6)$ & 0.109 & $3(3.5)$ & $7(8.2)$ & 0.395 \\
\hline G2 & $26(42.6)$ & $22(36.1)$ & & $30(35.3)$ & $29(34.1)$ & \\
\hline G3 & $5(8.2)$ & $4(6.6)$ & & $9(10.6)$ & $7(8.2)$ & \\
\hline \multicolumn{7}{|l|}{ N Classification } \\
\hline NO-N1 & $27(44.3)$ & $24(39.3)$ & 0.454 & $36(42.4)$ & $40(47.1)$ & 0.273 \\
\hline N2-N3 & $4(6.6)$ & $6(9.8)$ & & $6(7.1)$ & $3(3.5)$ & \\
\hline Tumor stage & & & & & & \\
\hline । & $3(4.9)$ & $3(4.9)$ & 0.216 & $4(4.7)$ & $9(10.6)$ & 0.247 \\
\hline$\|$ & 19 (31.1) & $12(19.7)$ & & $21(24.7)$ & $22(25.9)$ & \\
\hline III & $9(14.8)$ & $15(24.6)$ & & $17(20.0)$ & $12(14.1)$ & \\
\hline Molecular subtype & & & & & & \\
\hline Luminal A & $1(1.6)$ & $2(3.3)$ & 0.4455 & $4(4.7)$ & $8(9.4)$ & 0.182 \\
\hline Luminal B & 17 (27.9) & $18(29.5)$ & & $19(22.4)$ & $22(25.9)$ & \\
\hline Her2 overexpression & $4(6.6)$ & $6(9.8)$ & & $8(9.4)$ & $5(5.9)$ & \\
\hline Triple-negative & $9(14.8)$ & $4(6.6)$ & & $10(11.8)$ & $8(9.4)$ & \\
\hline Estrogen receptors & & & & & & \\
\hline Positive & $22(36.1)$ & $25(41.0)$ & 0.250 & $30(35.3)$ & $18(21.2)$ & 0.532 \\
\hline Negative & $9(14.8)$ & $5(8.2)$ & & $12(14.1)$ & $15(17.6)$ & \\
\hline Progesterone recepto & & & & & & \\
\hline Positive Negative & $22(36.1) 9(14.8)$ & $19(31.1) 11$ (18.0) & 0.525 & $\begin{array}{l}27(31.8) \\
15(17.6)\end{array}$ & $\begin{array}{l}29(34.1) \\
14(16.5)\end{array}$ & 0.759 \\
\hline HER2 & & & & & & \\
\hline Positive Negative & 5 (8.2) 26 (42.6) & $12(19.7) 18(29.5)$ & $<0.0376$ & $\begin{array}{l}9(10.6) \\
33(38.8)\end{array}$ & $\begin{array}{l}9(10.6) \\
34(40.0)\end{array}$ & 0.955 \\
\hline Histological type & & & & & & \\
\hline Ductal & $23(37.7)$ & $23(37.7)$ & 0.584 & $26(30.6)$ & $32(37.6)$ & 0.154 \\
\hline Lobular & $3(4.9)$ & $1(1.6)$ & & $1(1.2)$ & $3(3.5)$ & \\
\hline Other & $5(8.2)$ & $6(9.8)$ & & 15 (17.6) & $8(9.4)$ & \\
\hline Recurrence type & & & & & & \\
\hline Locoregional & $0(0.0)$ & $24(39.3)$ & $<0.0001$ & - & - & - \\
\hline Distant metastasis & $19(31.1)$ & $18(29.5)$ & & - & - & \\
\hline
\end{tabular}


locoregional breast recurrence compared with those in patients with recurrence in regions more distal to the tumor such as liver, brain and bones [15, 38].

Friesenhengst et al. [11] showed that CYP19A1 mRNA levels were significantly elevated in postmenopausal breast cancer patients. Tüzüner et al. [39] showed that the expression levels of the CYP19A1 gene were significantly decreased in patients older than 50 years. However, in agreement with our results, many studies have not shown any association between CYP19A1 gene expression and variables such as age, tobacco use, menopausal status, grade, nodal status, tumor stage, estrogen receptor, progesterone and histological type [18, 28, 29, 32, 37].

\section{Conclusion}

The present study found no significant differences between women with high and low expression of the CYP19A1 gene mRNA or between those in the study and control groups. However, in women with recurrence, there was increased expression of CYP19A1 mRNA in those who had the luminal hybrid subtype and locoregional relapse and decreased expression in those negative for HER2; nevertheless, further studies should be performed to consolidate the findings of the present study.

\section{Abbreviations}

ACTB: Beta-actin; CDNA: Complementary DNA; CT: Threshold cycle; N: Nodal status; RT: Reverse transcription; RT-PCR: Reverse transcription polymerase chain reaction

\section{Acknowledgements}

The authors thank the patients who participated in the current study and the Postgraduate Program of the Federal University of Piauí, Brazil.

\section{Authors' contributions \\ MCBO, DRCS, LCCV, ROP, RAS conceived the study idea, interpreted the data, wrote and revised the manuscript. PTMB, EBS, ALPS and PVLC participated in the design, coordination of the study, interpreted the data, and wrote and revised the manuscript. ARS, IMRSL, JLV, MAM and FMN collected the materials and conducted data extraction. EGC, MPC, VCS, LHG and BBS analyzed and interpreted the data and revised the manuscript. All authors have read and approved the manuscript.}

\section{Funding}

The all authors declare no Funding.

\section{Availability of data and materials}

The datasets used and/or analysed during the current study are available from the corresponding author on reasonable request.

\section{Ethics approval and consent to participate}

This study was approved by the Internal Review Board of the Federal University of Piauí and Perola Byington Hospital of the Federal University of Piauí. The written informed consent to participate in the study was be obtained from all participants. No animal was involved in this study.

\section{Consent for publication}

Not applicable.

\section{Competing interests}

The authors declare that they have no competing interests.

\section{Author details}

${ }^{1}$ Postgraduate Program of the Northeast Network of Biotechnology (RENORBIO), Teresina, Northeast, Brazil. ${ }^{2}$ Federal University of Piaui, Teresina, Piaui, Brazil. ${ }^{3}$ Mastology Unit, Getulio Vargas Hospital, Teresina, Piaui, Brazil.

${ }^{4}$ Perola Byington Hospital, São Paulo, São Paulo, Brazil.

Received: 27 November 2019 Accepted: 19 May 2020

Published online: 27 May 2020

\section{References}

1. Bray F, Ferlay J, Soerjomataram I, Siegel RL, Torre LA, Jemal A. Global cancer statistics 2018: GLOBOCAN estimates of incidence and mortality worldwide for 36 cancers in 185 countries. CA Cancer J Clin. 2018;68:394-424.

2. Ferlay J, Colombet M, Soerjomataram I, Mathers C, Parkin DM, Piñeros M, et al. Estimating the global cancer incidence and mortality in 2018: GLOBOCAN sources and methods. Int J Cancer. 2019;144:1941-53.

3. Ghoncheh M, Pournamdar Z, Salehiniya H. Incidence and mortality and epidemiology of breast Cancer in the world. Asian Pac J Cancer Prev. 2016; S3:43-6.

4. Quintanilha LF, Souza LN, Sanches D, Demarco RS, Fukutani KF. The impact of cancer campaigns in Brazil: a Google trends analysis. Ecancermedicalscience. 2019;13:963.

5. Jemal A, Thun MJ, Ries LA, Howe HL, Weir HK, Center MM, et al. Annual report to the nation on the status of cancer, 1975-2005, featuring trends in lung cancer, tobacco use, and tobacco control. J Natl Cancer Inst. 2008;100: 1672-94.

6. Gerber B, Freund M, Reimer T. Recurrent breast cancer: treatment strategies for maintaining and prolonging good quality of life. Dtsch Arztebl Int. 2010; 107:85-91.

7. Voinea SC, Sandru A, Blidaru A. Management of Breast Cancer Locoregional Recurrence. Chirurgia (Bucur). 2017;112:429-35.

8. Anderson KN, Schwab RB, Martinez ME. Reproductive risk factors and breast cancer subtypes: a review of the literature. Breast Cancer Res Treat. 2014; 144:1-10.

9. Costa-Silva DR, da Conceição B-OM, Borges RS, Campos-Verdes LM, da SilvaSampaio JP, Escorcio-Dourado CS, et al. Insulin-like growth factor 1 gene polymorphism in women with breast cancer. Med Oncol. 2017;34:59.

10. Campos-Verdes LM, da Silva-Sampaio JP, Costa-Silva DR, de Oliveira VA, Junior AMC, Silva VC, et al. Genetic polymorphism of calcium-sensing receptor in women with breast cancer. Med Oncol. 2018;35:23.

11. Friesenhengst A, Pribitzer-Winner T, Miedl H, Pröstling K, Schreiber M. Elevated aromatase (CYP19A1) expression is associated with a poor survival of patients with estrogen receptor positive breast Cancer. Horm Cancer. 2018;9:128-38.

12. Savolainen-Peltonen $W$, Wang $F$, Turpeinen $U$, Hämäläinen $E$, Haanpää $M$, et al. Estrogen biosynthesis in breast adipose tissue during menstrual cycle in women with and without breast cancer. Gynecol Endocrinol. 2018;34: 1039-43.

13. Simpson E, Santen RJ. Celebrating 75 years of oestradiol. J Mol Endocrinol. 2015:55:T1-20.

14. Zhao H, Zhou L, Shangguan AJ, Bulun SE. Aromatase expression and regulation in breast and endometrial cancer. J Mol Endocrinol. 2016:57:R19-33.

15. Bulun SE, Lin Z, Imir G, Amin S, Demura M, Yilmaz B, et al. Regulation of aromatase expression in estrogen-responsive breast and uterine disease: from bench to treatment. Pharmacol Rev. 2005;57:359-83.

16. Amatori S, Persico G, Fanelli M. Real-time quantitative PCR array to study drug-induced changes of gene expression in tumor cell lines. J Cancer Metastasis Treat. 2017:3:90-9.

17. E Hadi H, Abdellaoui-Maane I, Kottwitz D, E Amrani M, Bouchoutrouch N, Qmichou Z, et al. Development and evaluation of a novel RT-qPCR based test for the quantification of HER2 gene expression in breast cancer. Gene 2017; 605:114-122.

18. Miyoshi $Y$, Ando A, Hasegawa S, Ishitobi M, Taguchi T, Tamaki Y, et al. High expression of steroid sulfatase mRNA predicts poor prognosis in patients with estrogen receptor-positive breast cancer. Clin Cancer Res. 2003;9:2288-93.

19. Cardoso F, Costa A, Norton L, Senkus E, Aapro M, André F, et al. ESO-ESMO 2nd international consensus guidelines for advanced breast Cancer (ABC2). Breast. 2014;23:489-502.

20. Bustin SA, Mueller R. Real-time reverse transcription PCR (qRT-PCR) and its potential use in clinical diagnosis. Clin Sci (Lond). 2005;109:365-79. 
21. Wang $\mathrm{S}, \mathrm{Xu}$ J, Zhang Q. Clinical significance of survivin and vascular endothelial growth factor mRNA detection in the peripheral whole blood of breast cancer patients. Neoplasma. 2016;63:133-40.

22. Gilbey AM, Burnett D, Coleman RE, Holen I. The detection of circulating breast cancer cells in blood. J Clin Pathol. 2004;57:903-11.

23. Yie SM, Luo B, Ye NY, Xie K, Ye SR. Detection of Survivin-expressing circulating cancer cells in the peripheral blood of breast cancer patients by a RT-PCR ELISA. Clin Exp Metastasis. 2006;23:279-89.

24. Sharma P, Sahni NS, Tibshirani R, Skaane P, Urdal P, Berghagen H, et al. Early detection of breast cancer based on gene-expression patterns in peripheral blood cells. Breast Cancer Res. 2005;7:R634-44.

25. Aarøe J, Lindahl T, Dumeaux V, Saebø S, Tobin D, Hagen N, et al. Gene expression profiling of peripheral blood cells for early detection of breast cancer. Breast Cancer Res. 2010;12:R7.

26. Pignatti E, Casarini L, Scaltriti S, Wistuba J, Schlatt S, Rossi A, et al. Aromatase expression in human peripheral blood leucocytes (PBLs) and in various tissues in primates: studies in elderly humans and cynomolgus monkeys. J Med Primatol. 2012;41:372-83.

27. Stratakis CA, Vottero A, Brodie A, Kirschner LS, DeAtkine D, Lu Q, et al. The aromatase excess syndrome is associated with feminization of both sexes and autosomal dominant transmission of aberrant P450 aromatase gene transcription. J Clin Endocrinol Metab. 1998;83:1348-57.

28. Girault I, Lerebours F, Tozlu S, Spyratos F, Tubiana-Hulin M, Lidereau R, et al. Real-time reverse transcription PCR assay of CYP19 expression: application to a well-defined series of post-menopausal breast carcinomas. J Steroid Biochem Mol Biol. 2002:82:323-32.

29. Licznerska BE, Wegman PP, Nordenskjold B, Wingren S. In situ levels of oestrogen producing enzymes and its prognostic significance in postmenopausal breast cancer patients. Breast Cancer Res Treat. 2008;112:15-23.

30. Darlix A, Griguolo G, Thezenas S, Kantelhardt E, Thomssen C, Dieci MV, et al. Hormone receptors status: a strong determinant of the kinetics of brain metastases occurrence compared with HER2 status in breast cancer. J Neuro-Oncol. 2018;138:369-82.

31. Brown KA, lyengar NM, Zhou XK, Gucalp A, Subbaramaiah $K$, Wang $H$, et al. Menopause is a determinant of breast aromatase expression and its associations with BMI, inflammation, and systemic markers. J Clin Endocrinol Metab. 2017:102:1692-701.

32. Bollet MA, Savignoni A, De Koning L, Tran-Perennou C, Barbaroux C, Degeorges $\mathrm{A}$, et al. Tumor aromatase expression as a prognostic factor for local control in young breast cancer patients after breast-conserving treatment. Breast Cancer Res. 2009;11:R54.

33. Salhab M, Reed MJ, Al Sarakbi W, Jiang WG, Mokbel K. The role of aromatase and 17-beta-hydroxysteroid dehydrogenase type $1 \mathrm{mRNA}$ expression in predicting the clinical outcome of human breast cancer. Breast Cancer Res Treat. 2006;99:155-62.

34. Subbaramaiah K, Howe LR, Port ER, Brogi E, Fishman J, Liu CH, et al. HER-2/neu status is a determinant of mammary aromatase activity in vivo: evidence for a cyclooxygenase-2-dependent mechanism. Cancer Res. 2006;66:5504-11.

35. Harris RE, Robertson FM, Abou-Issa HM, Farrar WB, Brueggemeier R. Genetic induction and upregulation of cyclooxygenase (COX) and aromatase (CYP19): an extension of the dietary fat hypothesis of breast cancer. Med Hypotheses. 1999;52:291-2.

36. Brueggemeier RW, Díaz-Cruz ES, Li PK, Sugimoto Y, Lin YC, Shapiro CL. Translational studies on aromatase, cyclooxygenases, and enzyme inhibitors in breast cancer. J Steroid Biochem Mol Biol. 2005;95:129-36.

37. Yoshimura N, Harada N, Bukholm I, Kåresen R, Børresen-Dale AL, Kristensen VN. Intratumoural mRNA expression of genes from the oestradiol metabolic pathway and clinical and histopathological parameters of breast cancer. Breast Cancer Res. 2004;6:R46-55.

38. Zhang Z, Yamashita H, Toyama T, Omoto Y, Sugiura H, Hara Y, Wu X, Kobayashi S, Iwase $\mathrm{H}$. Quantitative determination, by real-time reverse transcription polymerase chain reaction, of aromatase mRNA in invasive ductal carcinoma of the breast. Breast Cancer Res. 2003;5:R250-6.

39. Tüzüner MB, Öztürk T, Eronat AP, Seyhan F, Kısakesen Hil, Calay Z, et al. Evaluation of local CYP17A1 and CYP19A1 expression levels as prognostic factors in postmenopausal invasive ductal breast Cancer cases. Biochem Genet. 2016;54:784-802.

\section{Publisher's Note}

Springer Nature remains neutral with regard to jurisdictional claims in published maps and institutional affiliations.

\section{Ready to submit your research? Choose BMC and benefit from:}

- fast, convenient online submission

- thorough peer review by experienced researchers in your field

- rapid publication on acceptance

- support for research data, including large and complex data types

- gold Open Access which fosters wider collaboration and increased citations

- maximum visibility for your research: over $100 \mathrm{M}$ website views per year

At BMC, research is always in progress.

Learn more biomedcentral.com/submissions 